\title{
Overall Reduction Kinetics of Low-grade Pyrolusite Using a Mixture of Hemicellulose and Lignin as Reductant
}

DOI: $10.15255 /$ KUI.2015.033 KUI-34/2015 Original scientific paper Received June 30, 2015 Accepted July 16, 2015

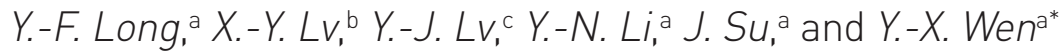 \\ a School of Chemistry and Chemical Engineering, Guangxi University, \\ Nanning 530 004, P.R. China \\ b The New Rural Development Research Institute, Guangxi University, \\ Nanning 530 004, P.R. China \\ c College of Chemistry and Bioengineering, Guilin University of Technology, \\ Guilin 541 004, P.R. China
}

\begin{abstract}
\| Abstract
Manganese is widely used in many fields. Many efforts have been made to recover manganese from low-grade pyrolusite due to the depletion of high-grade manganese ore. Thus, it is of practical significance to develop a clean, energy-saving and environmentally friendly technical route to reduce the low-grade pyrolusite.

The reported results show that biomass wastes from crops, crop waste, wood and wood waste are environmentally friendly, energy-saving, and low-cost reducing agents for roasting reduction of low-grade pyrolusite.

Kinetics of the reduction reactions is necessary for an efficient design of biomass reduction of pyrolusite. Therefore, it is important to look for a general kinetics equation to describe the reduction of pyrolusite by different kinds of biomass, because there is a wide variety of biomass wastes, meaning that it is impossible to investigate the kinetics for each biomass waste.

In this paper, thermal gravimetric analysis and differential thermal analysis were applied to study the overall reduction kinetics of pyrolusite using a mixture of hemicellulose and lignin, two major components of biomass. Overall reduction process is the overlap of the respective reduction processes. A new empirical equation based on the Johnson-Mehl-Avrami equation can be used to describe the respective reduction kinetics using hemicellulose and lignin as reductants, and the corresponding apparent activation energy is $30.14 \mathrm{~kJ} \mathrm{~mol}^{-1}$ and $38.91 \mathrm{~kJ} \mathrm{~mol}^{-1}$, respectively. The overall kinetic model for the reduction of pyrolusite by the mixture of hemicellulose and lignin can be simulated by the summation of the respective kinetics by considering their mass-loss fractions, while a unit step function was used to avoid the invalid conversion data.

The obtained results in this work are necessary to understand the biomass reduction of pyrolusite and provide valuable assistance in the development of a general kinetics equation.
\end{abstract}

\section{\| Keywords}

Pyrolusite, reduction-roast, biomass, kinetics

\section{Introduction}

Manganese is widely used in many fields, such as steel production, preparation of dietary additives, fertilizers, cells and fine chemicals. To meet the ever increasing demand for manganese, together with the gradual depletion of high-grade manganese ore, many efforts have been made to recover manganese from low-grade pyrolusite. ${ }^{1} \mathrm{MnO}_{2}$ in pyrolusite is stable in both acid and alkaline oxidizing conditions, so the extraction of manganese from pyrolusite must be carried out under reducing conditions. Generally, there are two major technical routes to reduce pyrolusite: one is hydrometallurgical reduction, and the other is pyrometallurgical reduction. In hydrometallurgical reduction, many kinds of reducing agents $\left(\mathrm{SO}_{2}\right.$, molasses, glucose, $\mathrm{H}_{2} \mathrm{O}_{2}, \mathrm{FeSO}_{4}$, etc.) have been used to reduce the manganese dioxide of the ores in acid medium..$^{1-2}$ However, hydrometallurgical reduction method has not been widely applied in commercial practice because of its complicated

* Corresponding author: Prof. Yan-Xuan Wen

e-mail: wenyanxuan@vip.163.com purification process and serious water pollution. ${ }^{2}$ Pyrometallurgical reduction method with coal as reducing agent is a conventional technology to treat low-grade pyrolusite, ${ }^{1,3}$ but this method produces a great deal of pollutants, including smoke dust, oxysulphides, nitrogen oxides, and so on. ${ }^{1,4}$ Moreover, it requires a reaction temperature of above $900{ }^{\circ} \mathrm{C}$, which most reactors cannot withstand. ${ }^{1,5-7}$ Thus, it is of practical significance to develop a clean, energy-saving, and environmentally friendly technical route to reduce the low-grade pyrolusite.

Recently, many kinds of waste from crops, crop waste, wood and wood waste (briefly named as biomass wastes), such as sawdust, straw, cornstalk, bagasse and bagasse pith, have been investigated as a possible reducing agent to overcome such problems. ${ }^{8-14}$ The results have shown that these biomass wastes can reduce manganese oxide of the ore at temperatures below $600{ }^{\circ} \mathrm{C}$ with a degree of reduction of more than $95 \%$. For example, Cheng et al. ${ }^{8}$ has reported that low-grade manganese dioxide ores can be totally reduced by biomass cornstalk at $500{ }^{\circ} \mathrm{C}$. Yang ${ }^{11}$ and Long ${ }^{9}$ found that low-grade pyrolusite can be reduced 
completely by bagasse at $450{ }^{\circ} \mathrm{C}$. Zhou ${ }^{14}$ has reported that pyrolusite can be reduced by bagasse pith at $350{ }^{\circ} \mathrm{C}$. Moreover, biomass reduction is a zero emission processes, because the amount of $\mathrm{CO}_{2}$ released during the reduction process is equal to that absorbed during biomass growth. ${ }^{15}$ Hence, biomass can be considered an environmentally friendly, energy-saving, and low-cost reducing agent for roasting reduction of manganese dioxide ores.

Meanwhile, a comprehensible understanding of the thermal reduction process and kinetics of the reduction reactions is required for an efficient design of biomass reduction of pyrolusite. FT-IR (Fourier Transform Infrared Spectroscopy) and Py-GC-MS (Pyrolysis-gas chromatography-mass spectrometry) results on the thermal reduction process indicate that the reduction of pyrolusite is related to the pyrolysis of biomass. ${ }^{14,16}$ Based on the hypothesis of first-order reaction, the Coats-Redfern method ${ }^{17}$ was used to determine the activation energy of the non-isothermal reduction of manganese oxide ore by biomass, such as straw, sawdust, wheat stalk and bamboo, and some valuable conclusions and insights have been obtained. ${ }^{18-20}$ However, there is a wide variety of biomass, meaning that it is impossible to investigate kinetics for each biomass. Therefore, it is necessary to look for a general kinetic equation to describe the reduction of pyrolusite by different kinds of biomass.

Although many types of biomass wastes are used in the reduction of pyrolusite, they all contain three major components - cellulose, hemicelluloses and lignin..$^{21-22}$ Each component of biomass has different molecular structure and nature so that the pyrolysis processes have different characteristics and generate different kinds of gas products, ${ }^{23-27}$ which results in varied reduction behaviours of pyrolusite. Suggested is the superposition of the reduction behaviour of three major components. Thus, the elucidation of the reduction behaviour of individual components and their mixtures is essential for the better understanding of the reduction mechanism and obtaining the general kinetic equation for reduction of pyrolusite by different types of biomass. However, the research results concerning individual biomass and mixtures of biomass components during the reduction of pyrolusite are limited.

In this work, thermogravimetric analysis and differential thermogravimetry (TG, DTG) were used to investigate the overall kinetics for the reduction-roast of pyrolusite with the mixture of hemicellulose and lignin reduction, two major components of biomass. A new empirical model function based on the Johnson-Mehl-Avrami equation (JMA) was used to describe the kinetic behaviours of the respective reduction-roast processes using hemicellulose or lignin as reductants. On the assumption that the main components in biomass underwent individual thermo-reduction, a multicomponent kinetic model on the basis of the summation of the respective kinetics was developed to simulate the overall kinetics for the reduction of pyrolusite by the mixture of hemicellulose and lignin. The obtained information is necessary to understand the biomass reduction of pyrolusite and provide valuable assistance in the development of a general kinetics equation.

\section{Experiments}

Pyrolusite, collected from Guangxi, China, contained (by mass) $22.01 \% \mathrm{Mn}, 11.16 \mathrm{Fe}, 27.62 \% \mathrm{SiO}_{2}, 10.93 \%$ $\mathrm{Al}_{2} \mathrm{O}_{3}, 0.09 \% \mathrm{CaO}, 0.12 \% \mathrm{MgO}, 0.020 \% \mathrm{~S}$, and 0.181 $\% \mathrm{P}$. The ore samples were crushed to $0.147 \mathrm{~mm}(-100$ meshes). Xylan extracted from beech wood was used as the representative of hemicelluloses. Lignin and hemicellulose were obtained from Sigma-Aldrich Corporation, USA. The hemicellulose and lignin were not further treated before mixing and testing. Table 1 gives the composition of the mixture of hemicellulose and lignin, where $w$ is the mass fraction for lignin and hemicellulose. Pyrolusite was mixed with hemicellulose, lignin or their mixtures, respectively. Based on the reported results, ${ }^{11}$ the mass ratio of pyrolusite to hemicellulose, lignin or their mixtures was $10: 1$. The reduction of pyrolusite by hemicellulose, lignin, and their mixture were named HP, LP, LH2, LH 4, LH 6, LH 7 and LH 8, respectively.

Table 1 -Composition of the mixture of hemicellulose and lignin

Tablica 1 - Sastav smjese hemiceluloze i lignina

\begin{tabular}{c|c|c|c|c|c|c}
\hline & LH2 & LH 3 & LH 4 & LH 6 & LH 7 & LH 8 \\
\hline$w$ (lignin) $\%$ & 0.20 & 0.30 & 0.40 & 0.60 & 0.70 & 0.80 \\
$w$ (hemicellulose) $/ \%$ & 0.80 & 0.70 & 0.60 & 0.40 & 0.30 & 0.20 \\
\hline
\end{tabular}

Thermogravimetric analyser (Q50TGA) was applied to investigate the mass loss of the reduction of pyrolusite by lignin, hemicellulose and their mixture. In the TG experiments, the sample was heated from room temperature to $800{ }^{\circ} \mathrm{C}$ at $20^{\circ} \mathrm{C} \mathrm{min}^{-1}$ in nitrogen atmosphere. The flow rate of nitrogen was $40 \mathrm{ml} \mathrm{min}{ }^{-1}$ to maintain an inert atmosphere for the decomposition. The mass of each sample was set at about $20 \mathrm{mg}$.

$\mathrm{X}$-ray diffraction $(\mathrm{XRD})$ patterns were obtained with a D8 Advance $\mathrm{X}$-ray diffractometer using $\mathrm{Cu}-\mathrm{K}_{\alpha}$ radiation with an accelerating voltage $40 \mathrm{kV}$, current $30 \mathrm{~mA}$, and scan speed $10^{\circ} \mathrm{min}^{-1}$ at $2 \theta=10^{\circ}-70^{\circ}$.

\section{Results and discussion}

\subsection{TG/DTG analysis}

TG/DTG experiments were carried out to measure the mass change during the reduction of pyrolusite by hemicellulose, lignin or their mixture under nitrogen at $20{ }^{\circ} \mathrm{C} \mathrm{min}-1$ heating rate. Fig. 1 presents the mass loss behaviours of the reduction of pyrolusite with hemicellulose or lignin, respectively. The mass loss behaviours of the reduction processes are also subdivided into three stages. The first stage (below $473 \mathrm{~K}$ ) was a loss in mass upon drying the sample, and mainly moisture was released at this stage. The second stage contributes to the main mass loss. The temperature range of the main mass loss stages are $493-663 \mathrm{~K}$ and $463-683 \mathrm{~K}$ for HP and LP, respectively. The maximum 

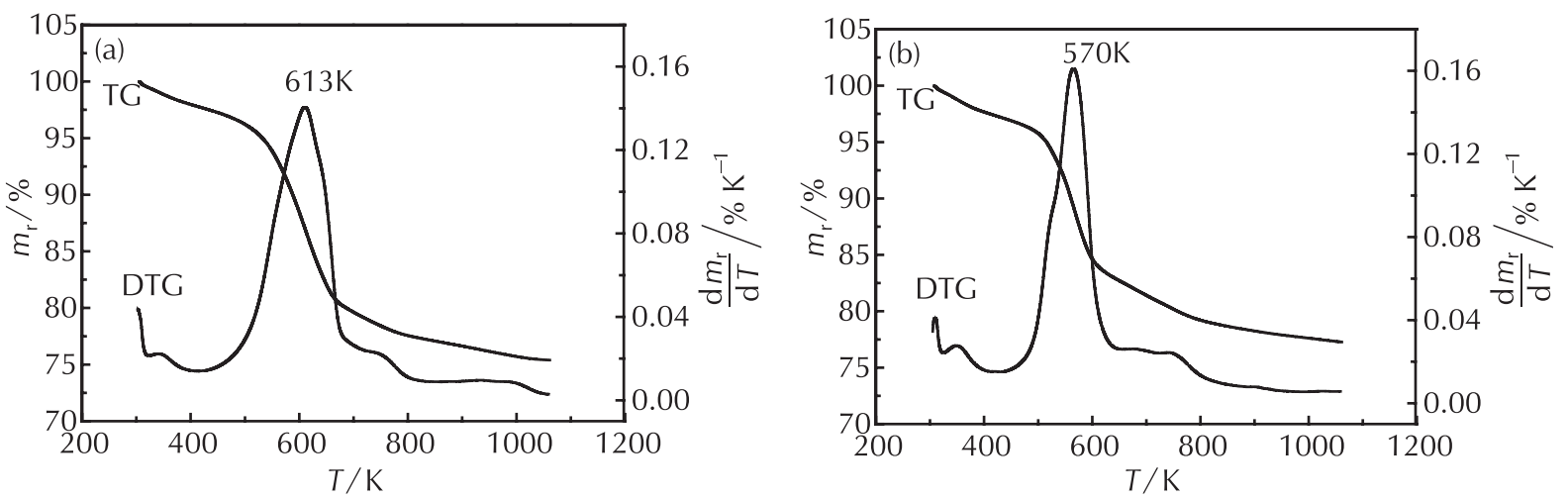

Fig. 1 - TG-DTG curves for the reduction of pyrolusite by lignin (a) and hemicellulose (b) at heating rate of $20 \mathrm{~K} \mathrm{~min}{ }^{-1}$ in nitrogen

Slika 1 - Termogrami TG-DTG redukcije piroluzita ligninom (a) i hemicelulozom (b) pri brzini zagrijavanja $20 \mathrm{~K} \mathrm{~min}{ }^{-1} \mathrm{u}$ dušiku

values of the DTG curve (mass loss rate) for HP and LP are at about $570 \mathrm{~K}$ and $613 \mathrm{~K}$, respectively. The last stage was high temperature charring of the residue and the mass loss was much lower.

XRD was used to identify the mineralogical composition of the ore samples before roast and after roast at $400{ }^{\circ} \mathrm{C}$ for 30 minutes. The corresponding XRD patterns are shown in Fig. 2. The original ore was comprised of pyrolusite $\left(\mathrm{MnO}_{2}\right)$, hematite $\left(\mathrm{Fe}_{2} \mathrm{O}_{3}\right)$, silicon oxide $\left(\mathrm{SiO}_{2}\right)$, while its roasted products were mainly manganese oxide $(\mathrm{MnO})$, hematite and kaolinite. Hence, the reduction processes of pyrolusite by hemicellulose and lignin were completed in the second stage of TG/DTG curves in Fig. 1.

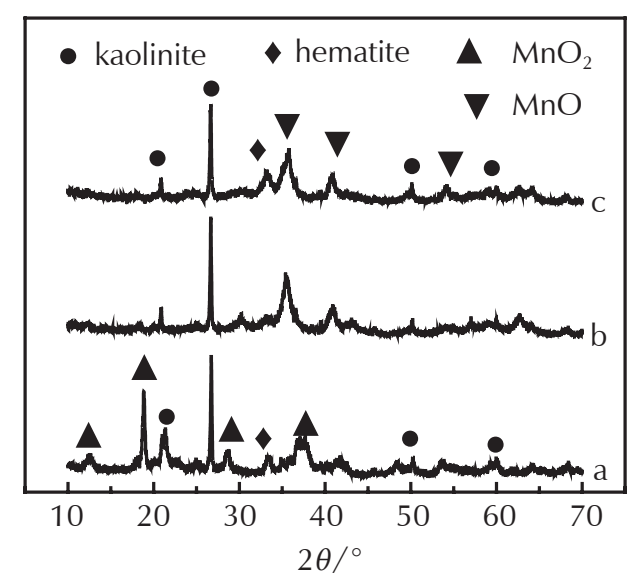

Fig. 2 - XRD patterns for the samples before roast (a - pyrolusite) and after roast ( $b-\mathrm{HP}$, and $\mathrm{c}-\mathrm{LP})$ at $400{ }^{\circ} \mathrm{C}$ for $30 \mathrm{~min}$

Slika 2 - Obrasci rendgenske difrakcije za uzorke prije (a - piroluzit) i poslije prženja (b-HP i c - LP) pri $400{ }^{\circ} \mathrm{C} \mathrm{u}$ trajanju od $30 \mathrm{~min}$
Fig. 3 presents the TG/DTG curves for the reduction of pyrolusite by the mixture of lignin and hemicellulose. The mass loss behaviours of the pyrolusite reduction processes by the mixture of lignin and hemicellulose are also subdivided into three stages, which are similar to those of the respective reduction processes shown in Fig. 1 . The main mass loss for the lignin-hemicellulose mixture reduction of pyrolusite is also concentrated in the second stage.

As shown in Fig. 3, the peaks related to lignin or hemicellulose reduction of pyrolusite cannot be distinguished, indicating that the respective reduction behaviours had overlapped in the pyrolusite reduction by the mixture of lignin and hemicellulose. Thus, the overall pyrolusite reduction processes by the mixture of lignin and hemicellulose are composed of respective reduction related to lignin and hemicellulose.

\subsection{Respective kinetic analysis}

According to the reported results, ${ }^{14,16,18}$ various reductive volatiles (such as aldehydes, furans, ketones, alcohol, etc.) were produced during the pyrolysis of biomass, which directly reduced $\mathrm{MnO}_{2}$ in the ore to $\mathrm{MnO}$. The pyrolusite reduction processes by biomass are complex, and involve many kinds of reductive volatiles with different molecular structure and nature. Zhang ${ }^{19}$ reported that reduction of low-grade manganese dioxide ore by wheat stalk obey the kinetic model

$$
\left[1-(1-\alpha)^{1 / 3}\right]^{2}=\frac{k t}{r^{2}}
$$



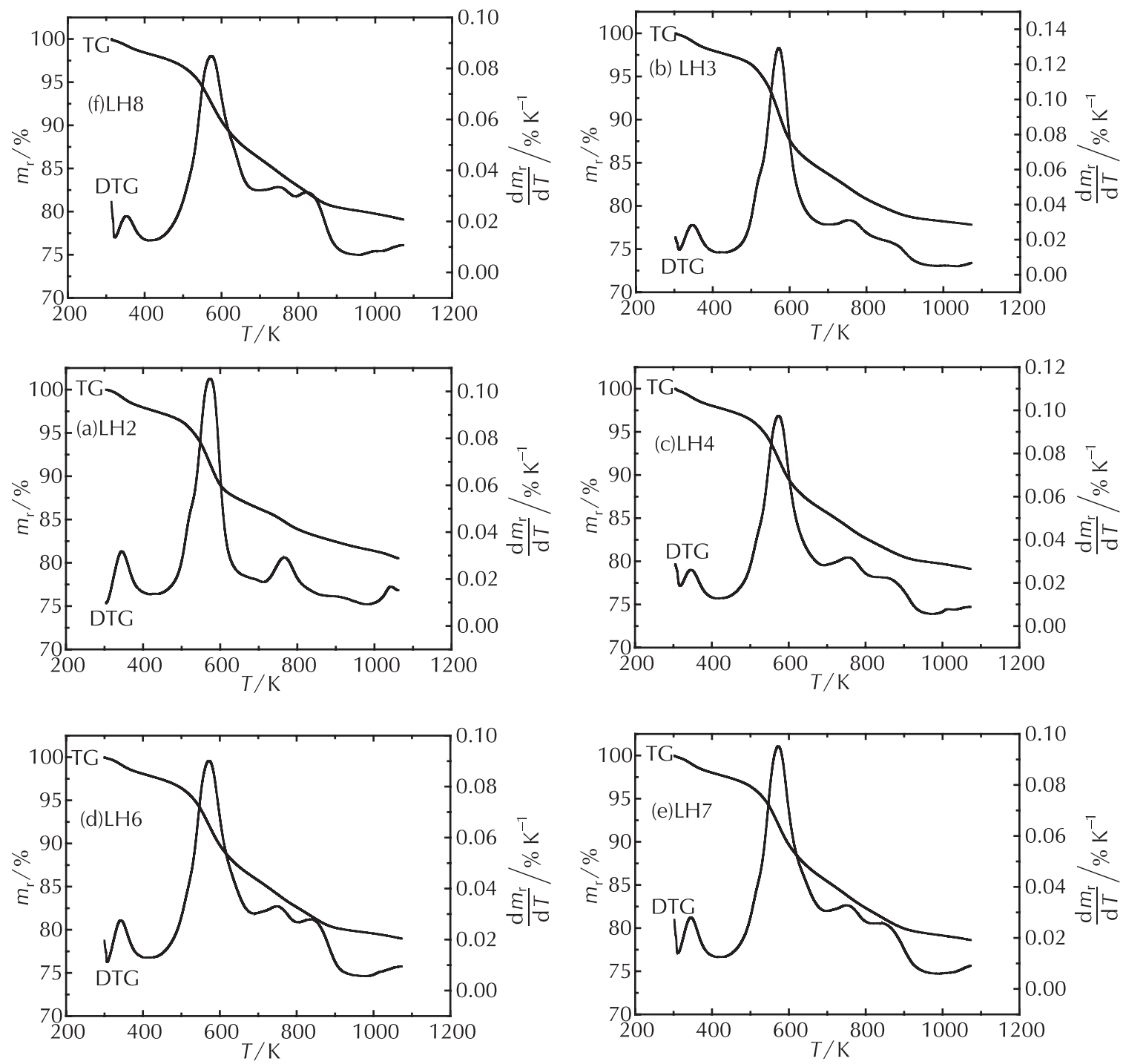

Fig. 3 - TG-DTG curves for the reduction of pyrolusite by the mixture of lignin and hemicellulose at heating rate of $20 \mathrm{~K} \mathrm{~min}^{-1}$ in nitrogen

Slika 3 - Krivulje TG-DTG za redukciju piroluzita mješavinom lignina i hemiceluloze pri brzini zagrijavanja $20 \mathrm{~K} \mathrm{~min}^{-1} \mathrm{u}$ dušiku

Bamboo, ${ }^{18-19}$ sawdust, ${ }^{19}$ wheat stalk ${ }^{19}$ and straw ${ }^{19-20}$ reduction of low-grade manganese dioxide ore can be described by:

$$
-\ln (1-\alpha)=k t
$$

Thus, biomass reduction of manganese dioxide ore under investigation cannot fully be described by the conventional kinetic model function $f(\alpha)$ because of the complexity of the reaction. ${ }^{28}$ In this case, it can be useful to find an empirical function containing the smallest possible number of constants, so that there is some flexibility sufficient to describe the real process as closely as possible.

The Johnson-Mehl-Avrami (JMA) equation, usually written in the following form:

$$
\alpha=1-\exp \left(-k t^{n}\right)
$$

where $k$ and $n$ are constants with respect to time $(t)$, and $\alpha$ is the degree of conversion. JMA equation has been used to describe the transformation kinetics of many solid 
state processes under isothermal conditions. ${ }^{29}$ When the temperature increases at a constant rate and $k$ can be expressed by Arrhenius equation,

$$
\begin{gathered}
T=T_{0}+\beta t \\
k=k_{0} \exp \left(-\frac{E_{\mathrm{a}}}{R T}\right)
\end{gathered}
$$

Eq. (3) can be rewritten as follows:

$$
\alpha=1-\exp \left[-k_{0} \exp \left(-\frac{E_{\mathrm{a}}}{R T}\right)\left(\frac{T-T_{0}}{\beta}\right)^{n}\right]
$$

where $\beta$ is the heating rate, $R$ is gas constant, $E_{\mathrm{a}}$ is apparent activation energy, $k_{0}$ is constant and $T_{0}$ is the initial temperature for the reaction determined from the DTG data. Hence, Eq. (6) is an empirical model based on JMA equation.

As indicated by the results of TG/DTG in Fig. 1, the reduction processes of pyrolusite by lignin and hemicellulose are concentrated at the second stage. The degree of conversion $(\alpha)$ for the reduction of pyrolusite can be calculated from the TG/DTG data according to the formula:

$$
\alpha=\frac{m_{0}-m_{\mathrm{T}}}{m_{0}-m_{\mathrm{F}}}
$$

where $m_{0}$ and $m_{\mathrm{F}}$ are the mass of the reaction mixture at initial and end stage, and $m_{\mathrm{T}}$ is the mass of the reaction mixture at temperature $T$. The degree of conversion $(\alpha)$ for the reduction of pyrolusite by lignin and hemicellulose was calculated and is given in Fig. 4.

The most appropriate parameters, $k_{0}, E_{\mathrm{a}}$ and $n$, of the respective reduction are calculated simultaneously by the nonlinear least square analysis to minimize the square sum of the residue when fitting the experimental curve of $\alpha_{\exp }$ versus temperature by the calculated curve of $\alpha_{\text {cal }}$ versus temperature.

$$
F=\sum_{j=1}^{M}\left(\alpha_{\text {exp,j }}-\alpha_{\mathrm{cal}, j}\right)^{2}
$$

The fitting results are presented in Table 2.

As seen in Fig. 4 and Table 2, the calculated conversion data agree well with the experimental data, and the correlation coefficients $\left(R_{\mathrm{kor}}^{2}\right)$ for the two reduction processes are greater than 0.99, indicating that these two reduction processes can be described by Eq. (6). The values of the apparent activation energy for the reduction of pyrolusite by lignin and hemicellulose are calculated to be $38.66 \mathrm{~kJ} \mathrm{~mol}^{-1}$ and $30.14 \mathrm{~kJ} \mathrm{~mol}^{-1}$, respectively.

Table 2 - Fitting results for the reduction of pyrolusite by lignin and hemicellulose

Tablica 2 - Parametri modela redukcije piroluzita ligninom i hemicelulozom

\begin{tabular}{l|c|c|c|c|c}
\hline $\begin{array}{l}\text { System } \\
\text { Sustav }\end{array}$ & $k_{0} / \mathrm{min}^{-n}$ & $E_{\mathrm{a}} / \mathrm{kJ} \mathrm{mol}^{-1}$ & $n$ & $T_{0} / \mathrm{K}$ & $R_{\mathrm{kor}}^{2}$ \\
\hline LP & 15.68 & 38.91 & 2.19 & 434.91 & 0.999 \\
HP & 4.23 & 30.14 & 2.69 & 451.66 & 0.996 \\
\hline
\end{tabular}
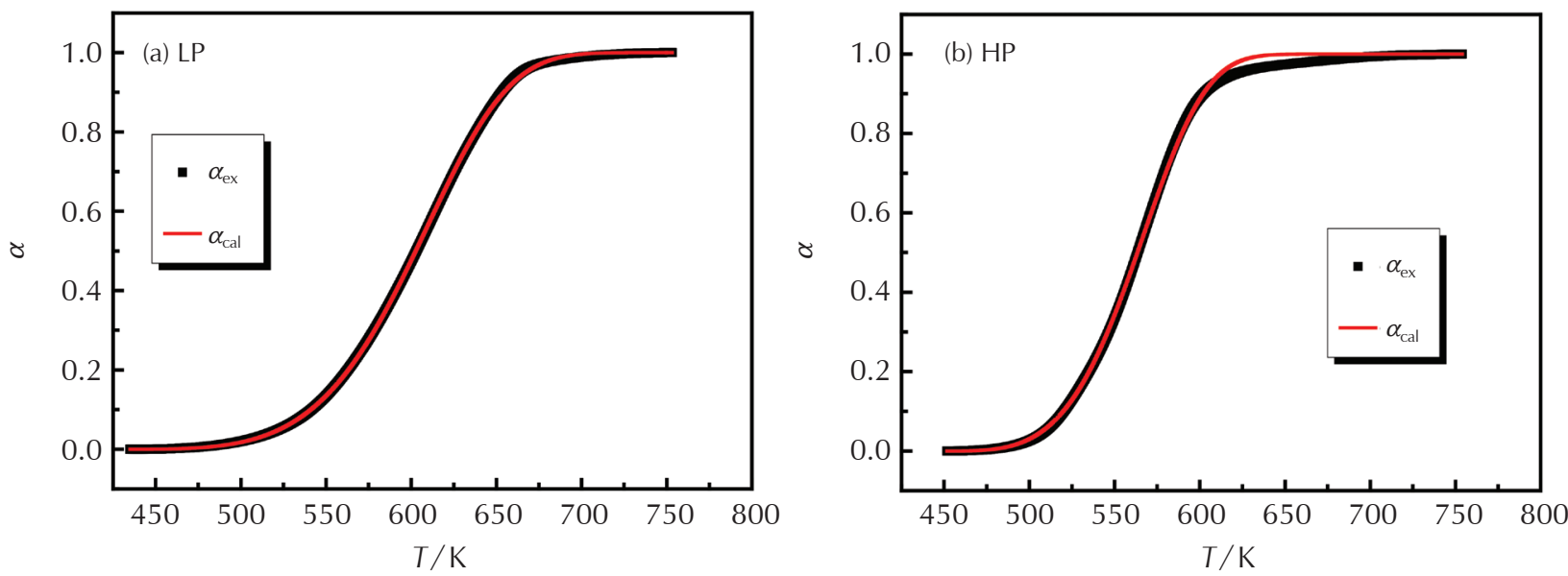

Fig. 4 - Respective kinetic analysis for LP (a) and HP (b) at heating rate of $20 \mathrm{~K} \mathrm{~min}^{-1}$ in nitrogen Slika 4 - Kinetička analiza za LP (a) i HP (b) pri brzini zagrijavanja $20 \mathrm{~K} \mathrm{~min}^{-1}$ u dušiku 


\subsection{Overlapped kinetic analysis}

The results of TG/DTG in Fig. 3 show that the reduction of pyrolusite by the mixture of lignin and hemicellulose is an overall process composed of two respective reduction processes. As long as the overall processes are composed of $\mathrm{N}$ independent kinetic processes, the overall kinetic behaviour can be expressed by the summation of the respective kinetic processes $i$ by considering their mass-loss fractions, $w_{\mathrm{i}}$.

$$
\alpha=\sum_{i} w_{i} \alpha_{i} \quad \sum_{i} w_{i}=1
$$

As seen in Table 3, initial temperatures $\left(T_{0}\right)$ are different from each other. For instance, initial temperature of $\mathrm{LH} 2$ is lower than that of HP and LP, meaning that there are invalid conversion data calculated by Eq. (6). This problem can be avoided by using a unit step function $\mu$ as following form.

$$
\alpha \mu\left(T-T_{0}\right)= \begin{cases}0, & T-T_{0} \leq 0 \\ \alpha, & T-T_{0}>0\end{cases}
$$

After substitution of Eq. (10) into Eq. (9), the following overall kinetic equation can be obtained:

$$
\alpha=\sum_{i} w_{i} \alpha_{i} \mu\left(T-T_{0, i}\right) \quad \sum_{i} w_{i}=1
$$

After substitution of Eq. (6) and the data in Table 2 into Eq. (11), the overall kinetic equation can be expressed by the following equation:

$$
\begin{aligned}
& \alpha=w_{1}\left\{1-\exp \left[-15.68 \exp \left(-\frac{38910}{R T}\right)\left(\frac{T-434.91}{\beta}\right)^{2.19}\right]\right\} \mu(T-434.91) \\
& +w_{2}\left\{1-\exp \left[-4.23 \exp \left(-\frac{30140}{R T}\right)\left(\frac{T-451.66}{\beta}\right)^{2.81}\right]\right\} \mu(T-451.66) \\
& w_{1}+w_{2}=1
\end{aligned}
$$

The experimental conversion data $\left(\alpha_{\text {exp }}\right)$ for the reduction of pyrolusite by the mixture of lignin and hemicellulose were calculated using Eq. (6) from the TG/DTG data in Fig. 3. The corresponding calculated conversion data $\left(\alpha_{\text {cal }}\right)$ were calculated using Eq. (12). The values of $\alpha_{\text {exp }}$ and $\alpha_{\text {cal }}$ are given in Fig. 5. The following Eq. (13) was used to determine the adaptability of Eq. (12), and the corresponding results are given in Table 3 .

$$
\alpha_{\text {cal }}=B \cdot \alpha_{\text {exp }} \quad F=\sum_{i=1}^{N}\left(\alpha_{\text {cal, }, i}-\alpha_{\text {exp }, i}\right)^{2}
$$

If the value of $B$ in Eq. (13) is 1, the calculated data are the same as the experimental values.

As shown in Fig. 5, the calculated data are in agreement with the experimental data. From Table 3, it can be seen that values of $B$ for six samples are close to 1 , and the correlation coefficients $\left(R_{\mathrm{kor}}{ }^{2}\right)$ for these reduction processes are greater than 0.99, indicating that the reduction of pyrolusite by the mixture of lignin and hemicellulose can be simulated by Eq. (12).

Table 3 - Results of adaptability analysis of Eq. (6) and (12)

Tablica 3 - Rezultati analize jedn. (6) i (12)

\begin{tabular}{c|c|c|c|c|c|c|c|c}
\hline & HP & LH2 & LH 3 & LH 4 & LH 6 & LH 7 & LH 8 & LP \\
\hline$T_{0} / \mathrm{K}$ & 451.66 & 421.89 & 458.85 & 466.71 & 476.04 & 475.65 & 477.19 & 434.91 \\
$B$ & 1.011 & 0.985 & 0.995 & 0.994 & 0.994 & 0.989 & 0.986 & 1.002 \\
$R_{\text {kor }}{ }^{2}$ & 0.999 & 0.998 & 0.999 & 0.998 & 0.997 & 0.997 & 0.998 & 0.999 \\
$F$ & 0.184 & 0.389 & 0.539 & 0.962 & 0.956 & 0.964 & 0.812 & 0.020 \\
\hline
\end{tabular}



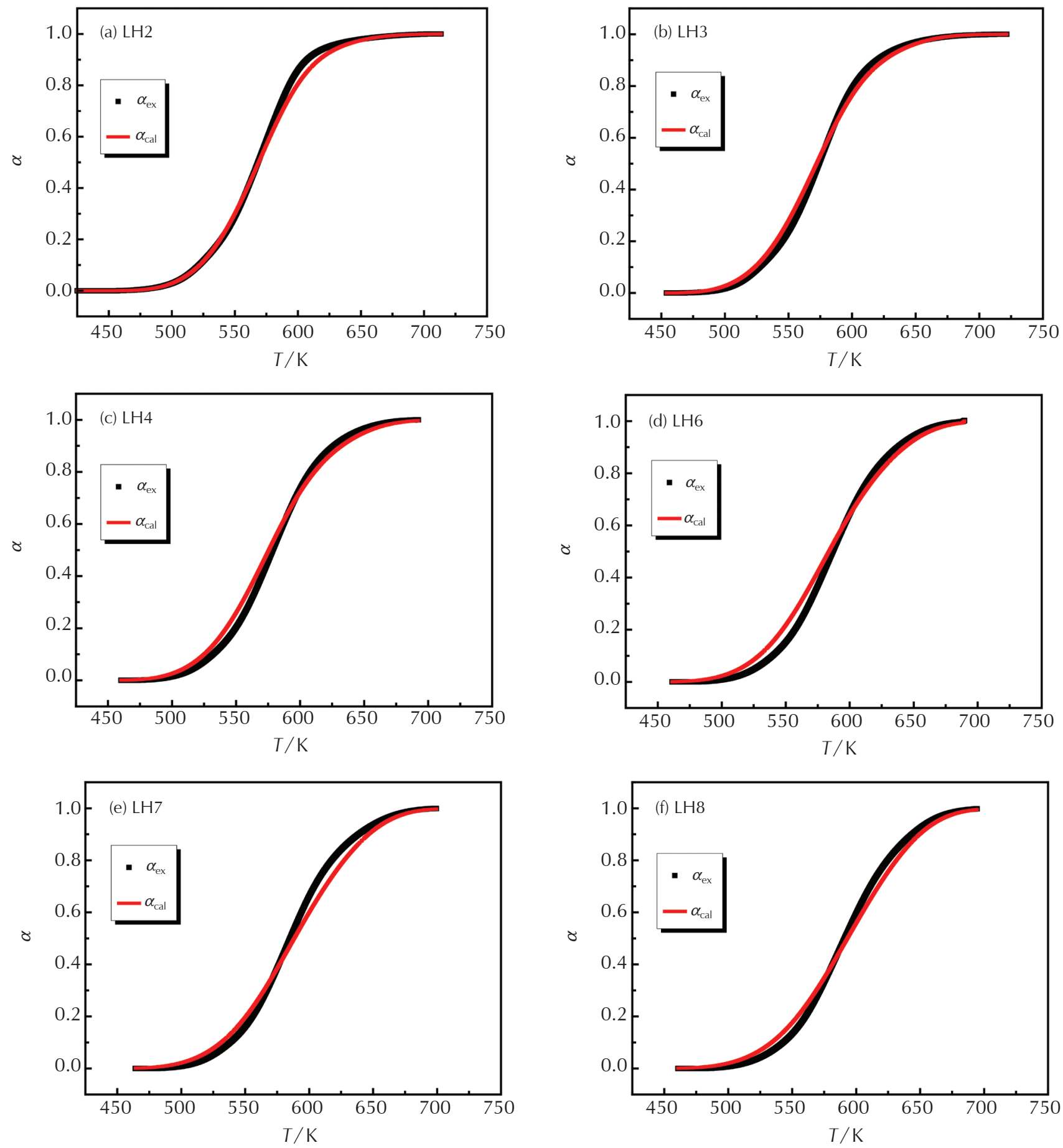

Fig. 5 - Overall kinetic analysis for the reduction of pyrolusite by the mixture of lignin and hemicellulose at heating rate of $20 \mathrm{~K} \mathrm{~min}^{-1}$ in nitrogen

Slika 5 - Ukupna kinetička analiza redukcije piroluzita smjesom lignina i hemiceluloze pri brzini zagrijavanja $20 \mathrm{~K}$ min $^{-1}$ u dušiku

\section{Conclusions}

Kinetics of the overall reduction processes of pyrolusite by the mixture of lignin and hemicellulose, two major components of biomass, were investigated. The TG/DTG and XRD results reveal that the mass loss behaviours of the reduction processes are subdivided into three stages, and the main reduction processes are concentrated in the second stage. The respective reduction processes of pyrolusite by lignin and hemicellulose are overlapped in the overall reduction processes. On the basis of JMA equation, an empirical equation was developed to describe the respective kinetics for the reduction of pyrolusite by lignin and hemicellulose. The apparent activation energy for the reduction of pyrolusite by hemicellulose and lignin was $30.14 \mathrm{~kJ} \mathrm{~mol}^{-1}$ and $38.91 \mathrm{~kJ} \mathrm{~mol}^{-1}$, respectively. The overall reduction kinetics can be simulated by the summation of the respective kinetics by considering their mass-loss fractions. 


\section{ACKNOWLEDGEMENTS}

We are grateful to the National Natural Science Foundation of China (21166003) and the Doctoral Foundation of Ministry of Education of China (20114501110004) for financial support.

\section{List of abbreviations and symbols Popis kratica i simbola}

\begin{tabular}{|c|c|}
\hline DTG & $\begin{array}{l}\text { - differential thermogravimetry } \\
\text { - diferencijalna termogravimetrija }\end{array}$ \\
\hline JMA & - Johnson-Mehl-Avrami \\
\hline \multicolumn{2}{|c|}{$\begin{aligned} \text { Py-GC-MS - pyrolysis-gas chromatography-mass spectrometry } \\
\text { - piroliza - plinska kromatografija - masena spektro- } \\
\text { metrija }\end{aligned}$} \\
\hline TG & $\begin{array}{l}\text { - thermogravimetry } \\
\text { - termogravimetrija }\end{array}$ \\
\hline XRD & $\begin{array}{l}\text { - X-ray diffraction } \\
\text { - rendgenska difrakcija }\end{array}$ \\
\hline$E_{\mathrm{a}}$ & $\begin{array}{l}\text { - apparent activation energy, } \mathrm{kJ} \mathrm{mol}^{-1} \\
\text { - prividna aktivacijska energija, } \mathrm{kJ} \mathrm{mol}^{-1}\end{array}$ \\
\hline$F$ & $\begin{array}{l}\text { - residual sum of squares } \\
\text { - rezidualni zbroj kvadrata }\end{array}$ \\
\hline k & $\begin{array}{l}\text { - constant, } \min ^{-\mathrm{n}} \\
\text { - konstanta, } \min ^{-\mathrm{n}}\end{array}$ \\
\hline$k_{0}$ & $\begin{array}{l}\text { - constant, } \min ^{-n} \\
\text { - konstanta, } \min ^{-n}\end{array}$ \\
\hline$m_{0}$ & $\begin{array}{l}\text { - mass of reaction mixture at initial stage, } \mathrm{mg} \\
\text { - početna masa reakcijske smjese, mg }\end{array}$ \\
\hline$m_{\mathrm{F}}$ & $\begin{array}{l}\text { - masa of reaction mixture at end stage, mg } \\
\text { - konačna masa reakcijske smjese, mg }\end{array}$ \\
\hline$m_{\mathrm{r}}$ & $\begin{array}{l}\text { - relative mass, } \% \\
\text { - relativna masa, } \%\end{array}$ \\
\hline$m_{\mathrm{T}}$ & $\begin{array}{l}\text { - masa of reaction mixture at temperature } T, \mathrm{mg} \\
\text { - masa reakcijske smjese pri temperaturi } T, \mathrm{mg}\end{array}$ \\
\hline$n$ & $\begin{array}{l}\text { - constanta } \\
\text { - konstanta }\end{array}$ \\
\hline$r$ & $\begin{array}{l}\text { - initial particle radius, } \mathrm{m} \\
\text { - početni promjer čestica, m }\end{array}$ \\
\hline$R$ & $\begin{array}{l}\text { - universal gas constant, } \mathrm{R}=8.314 \mathrm{~J} \mathrm{~K} \mathrm{~mol}^{-1} \\
\text { - opća plinska konstanta, } \mathrm{R}=8.314 \mathrm{~J} \mathrm{~K} \mathrm{~mol}^{-1}\end{array}$ \\
\hline$R_{\text {kor }}$ & $\begin{array}{l}\text { - correlation coefficient } \\
\text { - koeficijent determinacije }\end{array}$ \\
\hline$t$ & $\begin{array}{l}\text { - time, } \min \\
\text { - vrijeme, } \min \end{array}$ \\
\hline$T$ & $\begin{array}{l}\text { - temperature, } \mathrm{K} \\
\text { - temperatura, } \mathrm{K}\end{array}$ \\
\hline$T_{0}$ & $\begin{array}{l}\text { - initial temperature for the reaction, } \mathrm{K} \\
\text { - početna reakcijska temperatura, } \mathrm{K}\end{array}$ \\
\hline$w_{1}$ & $\begin{array}{l}\text { - mass fraction of lignin in the mixture } \\
\text { - maseni udjel lignina u smjesi }\end{array}$ \\
\hline$W_{2}$ & $\begin{array}{l}\text { - mass fraction of hemicellulose in the mixture } \\
\text { - maseni udjel hemiceluloze u smjesi }\end{array}$ \\
\hline$\alpha$ & $\begin{array}{l}\text { - degree of conversion } \\
\text { - stupanj konverzije }\end{array}$ \\
\hline$\alpha_{\text {cal }}$ & $\begin{array}{l}\text { - degree of conversion calculated from the model } \\
\text { - računati stupanj konverzije }\end{array}$ \\
\hline$\alpha_{\exp }$ & $\begin{array}{l}\text { - degree of conversion from TG/DTG experiment } \\
\text { - eksperimentalni stupanj konverzije }\end{array}$ \\
\hline
\end{tabular}

- heating rate, $\mathrm{K} \mathrm{\textrm {min } ^ { - 1 }}$

- brzina zagrijavanja, $\mathrm{K} \mathrm{min}^{-1}$

- unit step function

- jedinična odskočna funkcija

- diffraction angle, ${ }^{\circ}$

- difrakcijski kut,

\section{References \\ Literatura}

1. W. Zhang, C. Y. Cheng, Manganese metallurgy review. Part I: Leaching of ores/secondary materials and recovery of electrolytic/chemical manganese dioxide, Hydrometallurgy $\mathbf{8 9}$ (2007) 137-159, doi: http://dx.doi.org/10.1016/j.hydromet.2007.08.010.

2. I. De Michelis, F. Ferella, F. Beolchini, F. Vegliò, Reducing acid leaching of manganiferous ore: Effect of the iron removal operation on solid waste disposal, Waste. Manag. 29 (2009) 128-135, doi: http://dx.doi.org/10.1016/j.wasman.2008.03.012.

3. P. K. Sahoo, K. S. Rao, Sulphating-roasting of low grade manganese ore: optimization by factorial design, Int. J. Miner. Process 25 (1989) 147-152, doi: http://dx.doi. org/10.1016/0301-7516(89)90061-6.

4. C. Acharya, R. N. Kar, Studies on reaction mechanism of bioleaching of manganese ore, Miner. Eng. 16 (2003) 1027-1030, doi: http://dx.doi.org/10.1016/S08926875(03)00239-5.

5. C. Abbruzzese, Percolation leaching of manganese ore by aqueous sulfur dioxide, Hydrometallurgy 25 (1993) 85-97, doi: http://dx.doi.org/10.1016/0304-386X(90)90066-B.

6. A. A. Ismail, E. A.Ali, I. A. Ibrahim, M. S. Ahmed, A comparative study on acid leaching of low grade manganese ore using some industrial wastes as reductants, Can. J. Chem. Eng. 82 (2004) 1296-1300, doi: http://dx.doi.org/10.1002/ cjce.5450820618.

7. T. Jiang, Y. Yang, Z. Huang, G. Qiu, Simultaneous leaching of manganese and silver from manganese-silver ores at room temperature, Hydrometallurgy 69 (2003) 177-186, doi: http://dx.doi.org/10.1016/S0304-386X(03)00033-1.

8. Z. Cheng, G. Zhu, Y. N. Zhao, Study in reduction-roast leaching manganese from low-grade manganese dioxide ores using cornstalk as reductant, Hydrometallurgy 96 (2009) 176-179, doi: http://dx.doi.org/10.1016/j. hydromet. 2008.08.004.

9. Y. F. Long, J. Su, X. J. Ye, Reduction-roast leaching of lowgrade pyrolusite using bagasse as a reducing agent, Adv. Mater. Res. 699 (2013) 28-33, doi: http://dx.doi.org/10.4028/ www.scientific.net/AMR.699.28.

10. J. J. Song, G. Zhu, P. Zhang, Y. Zhao, Reduction of low-grade manganese oxide ore by biomass roasting, Acta Metall. Sin. (Engl. Lett.) 23 (2010) 223-229.

11. K. D.Yang, X. J. Ye, J. Su, H. F. Su, Y. F. Long, X. Y. Lv, Y. X. Wen, Response surface optimization of process parameters for reduction roasting of low-grade pyrolusite by bagasse, Trans. Nonferrous Met. Soc. China 23 (2013) 548-555, doi: http://dx.doi.org/10.1016/S1003-6326(13)62498-X.

12. H. L. Zhang, G. Zhu, H. Yan, Y. Zhao, F. Chen, W. Wang, An investigation on stability of biomass reduced manganese dioxide ore, Acta Metall. Sin. (Engl. Lett.) 25 (2012) 435-442.

13. H. Zhang, G. Zhu, H. Yan, Y. Zhao, T. Li, X. Feng, Reduction of low-grade manganese dioxide ore pellets by biomass wheat stalk, Acta Metall. Sin. (Engl. Lett.) 26 (2013) 167-172, doi: 
http://dx.doi.org/10.1007/s40195-012-0250-x.

14. Y. H. Zhou, H. Yao, Y. F. Long, J. Su, J. Liu, X. H. Zhou, T. Gang, Z. M. Lei, Y.X.Wen, Reduction roasting and leaching of lowgrade pyrolusite with bagasse pith at low temperature, Chin. J. Process Eng. 13 (2013) 946-951 (in Chinese).

15. M. Zhang, Y. C. Yuan, Y. Z. Liu, Research on biomass waste combustion technologies, Energy Res. Inform. 21 (2005) 15-19.

16. X. J. Ye, J. Su, H. F. Su, Y. F. Long, Y. X. Wen, Analysis of the bagasse roasting low-grade pyrolusite using TG-FTIR, J. Guangxi Uni.: Nat. Sci. Ed. 37 (3) (2012) 440-444 (in Chinese).

17. A. W. Coats, J. P. Redfern, Kinetic parameters from thermogravimetric data, Nature 201 (1964) 68-69, doi: http://dx. doi.org/10.1038/201068a0.

18. H. Zhang, G. Zhu, H. Yan, T. C. Li, Y. N. Zhao, The mechanism on biomass reduction of low-grade manganese dioxide ore, Metall. Mater. Trans. B 44B (2013) 889-896, doi: http://dx. doi.org/10.1007/s11663-013-9835-7.

19. H. Zhang, G. Zhu, H. Yan, T. Li, X. Feng, Thermogravimetric analysis and kinetics on reducing Low-grade manganese dioxide ore by biomass, Metall. Mater. Trans. B 44B (2013) 878-888, doi: http://dx.doi.org/10.1007/s11663-0139840-x.

20. Y. N. Zhao, G. Zhu, C. Zhuo, Thermal analysis and kinetic modeling of manganese oxide ore reduction using biomass straw as reductant, Hydrometallurgy 105 (2010) 96-102, doi: http://dx.doi.org/10.1016/j.hydromet.2010.08.004.

21. T. Qu, W. Guo, L. Shen, J. Xiao, K. Zhao, Experimental Study of Biomass Pyrolysis Based on Three Major Components: Hemicellulose, Cellulose, and Lignin, Ind. Eng. Chem. Res. 50 (2011) 10424-10433, doi: http://dx.doi.org/10.1021/ ie1025453.

22. S. V. Vassilev, D. Baxter, L. K. Andersen, C. G. Vassileva, T.
J. Morgan, An overview of the organic and inorganic phase composition of biomass, Fuel 94 (2012) 1-33, doi: http:// dx.doi.org/10.1016/j.fuel.2011.09.030.

23. L. Burhenne, J. Messmer, T. Aicher, M. P. Laborie, The effect of the biomass components lignin, cellulose and hemicellulose on TGA and fixed bed pyrolysis, J. Anal. Appl. Pyrol. 101 (2013) 177-184, doi: http://dx.doi.org/10.1016/j. jaap.2013.01.012.

24. A. Corma, S. Iborra, A. Velty, Chemical routes for the transformation of biomass into chemicals, Chem. Rev. 107 (2007) 2411-2502, doi: http://dx.doi.org/10.1021/cr050989d.

25. C. DiBlasi, C. Branca, A. Galgano, Biomass Screening for the Production of Furfural via Thermal Decomposition, Ind. Eng. Chem. Res. 49 (2010) 2658-2671, doi: http://dx.doi. org/10.1021/ie901731u.

26. S. Xin, H. Yang, Y. Chen, X. Wang, H. Chen, Assessment of pyrolysis polygeneration of biomass based on major components: Product characterization and elucidation of degradation pathways, Fuel 113 (2013) 266-273, doi: http://dx.doi. org/10.1016/j.fuel.2013.05.061.

27. H. Yang, R. Yan, H. Chen, D. H. Lee, C. Zheng, Characteristics of hemicellulose, cellulose and lignin pyrolysis, Fuel 86 (2007) 1781-1788, doi: http://dx.doi.org/10.1016/j. fuel.2006.12.013.

28. N. Koga, J. Malek, Accommodation of the actual solid-state process in the kinetic model function. Part 2. Applicability of the empirical kinetic model function to diffusion-controlled reactions, Thermochim. Acta 282/283 (1996) 69-80, doi: http://dx.doi.org/10.1016/0040-6031(96)02822-5.

29. A. Khawam, D. R. Flanagan, Solid-State Kinetic Models: Basics and Mathematical Fundamentals, J. Phys. Chem. B 110 (2006) 17315-17328, doi: http://dx.doi.org/10.1021/ jp062746a. 


\section{SAŽETAK}

\section{Ukupna kinetika redukcije niskokvalitetnog piroluzita smjesom hemiceluloze i lignina kao redukcijskog sredstva \\ Yun-Fei Long, ${ }^{a}$ Xiao-Yan Lv, ${ }^{\text {bi }}$-Ju Lv, ${ }^{c}$ Yogn-Ni Li, Jing Sua i Yan-Xuan Wen a*}

Ukupna kinetika redukcije piroluzita istraživana je termogravimetrijom i diferencijalnom termogravimetrijom. Kao redukcijsko sredstvo upotrijebljeni su hemiceluloza i lignin, glavni sastojci poljoprivrednog biljnog biootpada, drva i drvnog otpada. Ukupnu redukciju čine isprepleteni pojedinačni redukcijski procesi.

Kinetika redukcije piroluzita smjesom hemiceluloze i lignina može se opisati novom empirijskom jednadžbom temeljenoj na jednadžbi Johnson-Mehl-Avrami, a odgovarajuća prividna energija aktivacije iznosi $30.14 \mathrm{~kJ} \mathrm{~mol}^{-1}$, odnosno $38.91 \mathrm{~kJ} \mathrm{~mol}^{-1}$. Sveobuhvatna kinetika može se modelirati kao zbroj pojedinačnih udjela uzimajući u obzir masene udjele sastojaka smjese te uz primjenu jedinične odskočne funkcije kako bi se izbjegli nevaljani podaci.

Ključne riječi

Piroluzit, redukcijsko prženje, biomasa, kinetika

a School of Chemistry and Chemical Engineering, Guangxi University, Nanning 530004 , Kina

b The New Rural Development Research Institute, Guangxi University, Nanning 530004 , Kina

'College of Chemistry and Bioengineering, Guilin University of Technology, Guilin 541 004, Kina
Izvorni znanstveni rad Prispjelo 30. lipnja 2015. Prihvaćeno 16. srpnja 2015. 